\title{
Industrial Projects and Benefit-Sharing Arrangements in the Russian North. Is Contracting Possible?
}

\author{
Ekaterina Britcyna \\ Faculty of Law, University of Lapland, 96100 Rovaniemi, Finland; katya-bricyna@yandex.ru
}

Received: 18 March 2019; Accepted: 20 May 2019; Published: 31 May 2019

\begin{abstract}
The extractive industries and local communities in the Russian Arctic make socio-economic agreements to support social and environmental initiatives in the territories of their operations. The extractive industries address social responsibilities through grant projects and social investments. In the framework of social investments, major industrial corporations are supposed to distribute benefits obtained from resource exploitation to stakeholders who are affected by industrial operations. This article presents different forms of benefit-sharing arrangements and how they work in practice in the context of contracting for natural resources (oil, gas, metals and minerals) in Russia. The analysis outlines specific types of contracts and how they are implemented. While benefit-sharing arrangements can provide some benefits for local and regional stakeholders, it is controversial whether these arrangements can improve the situation as far as even-handed sharing of society's environmental risks, benefits, and impacts is concerned. The article discusses how voluntary social partnership agreements in line with corporate citizenship and stakeholder management can alleviate problems between local people and industries in the Russian Arctic.
\end{abstract}

Keywords: Benefit-sharing arrangements; extractive projects; natural resources; corporate citizenship; stakeholder management

\section{Introduction}

The concept of benefit-sharing has been a topical issue in international debates for the past two decades [1]. On the global scale, the Corporate Social Responsibility (CSR) of enterprises has been evolving for decades, and demands for increased local responsibility and benefit-sharing with extractive industries have grown [2,3]. Usually, the industrial enterprises provide benefits to the local communities, following the guidelines of their CSR policies. Benefit-sharing is a widespread CSR tool which is understood and applied differently in the various branches of international (mainly soft) law. In the legal field, there is no general definition of this concept $[1,3]$.

When considering the concept of benefit-sharing, it is crucial to define how benefits can be understood and precisely how benefits function in the context of the discourse on oil, gas and mining projects. Most of the mineral resources in Russia are in the Arctic. The region is rich in various unique natural resources which provide many opportunities for further exploration [4]. The communities, which live in harsh conditions, live and work in close vicinity to the industrial projects and face negative impacts from operations. The companies make socio-economic agreements with public and private stakeholders, stipulating the benefits a company agrees to provide in exchange for community support of projects and a favourable operating environment. The benefits may be expressed in both monetary and non-monetary form [5].

The business dictionary states that benefits are a "desirable and measurable outcome or result from an action, investment, project, resource, or technology" [6]. This short definition contains several applicable terms with relevance to the current discourse [7]. Actions, investments, projects, resources and technology are all crucial elements in the industrial projects in the Russian North, and several 
of these key notions also play an essential role in terms of CSR practices. It is relevant to discuss the incentives of extractive industries that operate in the Russian North. As with any other industrial venture, oil, gas and mining companies seek a return on investment and consequently revenues that outweigh the costs. When the profit margins are so narrow that they put a company's survival at risk, companies will be pressured to cut corners and pursue irresponsible courses of development $[8,9]$. Profit margins allow for survival in the markets and important business actions such as investments in infrastructure, expansion, modernization, social benefits, environmental protection, and more. The oil/gas and mining sectors are the backbone of the Russian economy, an economy that struggles to implement diversity, despite continuously expressing the political will to promote other sectors as well $[10,11]$. With the process of transition to a market economy, the legislation (formal rules) has been adjusted to the new realities, and informal rules (beliefs, values, habits) need time to adopt [12].

The oil industry in large parts of Russia is successful and creates important wealth for the Russian economy. Oil remains a crucial source of energy, and it is utilized in manufacturing as well. Particularly in remote areas without power plants, oil is often the easiest solution to run machines and facilities for energy and heating. Engineers have invented renewable energy solutions that can replace fossil fuels; however, at this date the achievements have not been sufficient to significantly decrease the importance of oil production in the socio-economic context of Russia [13].

Keeping in mind various forms of benefits that the industry creates for itself and the national economy, the question is: What benefit does the local society receive on the sites of extraction? To answer this, it is necessary to understand that the local society in the Russian North is not homogenous. The people have different backgrounds, different opinions, different objectives, and even different cultural heritage [14]. Thus, opinions concerning the extractive industry and, therefore, the perceived benefits are diverse.

The extractive industries in Russia point to their contribution to infrastructure development, health care provision, pension support, and efforts to improve education and recreational activities. These corporate actions of providing social benefits as a form of charity have a long tradition in the Russian North, going back to the Soviet era $[15,16]$. Another benefit to certain members of local societies may be employment in cases where a company offers positions and training to get the necessary qualification to work in the industry. How much benefit everyone receives depends on the specific needs that individuals have with respect to the charity provisions [17].

The ecological challenges and performances of the extractive industries also play a significant role. Substantial amounts of oil are spilled with disturbing regularity but are seldom reported [18]. Oil spills, greenhouse gas emissions and other forms of pollution impact the health, livelihoods and well-being of the members of the local society. The question is whether it is possible and desired by local communities to receive compensation from the industry in the form of economic benefits generated as a result of resource depletion. Local communities increasingly ask for benefits to offset negative impacts caused by new extraction projects. These requests often take the form of negotiated agreements. However, agreements are the subject of some debate, especially regarding their effectiveness and fairness. There is no consensus regarding the fair distribution of benefits, functions and responsibilities of the parties to the agreements [6].

The utilization of natural resources is directly connected to the issue of property, which reflects a threefold nature: (a) resources as a national wealth, (b) resources as commodities, and (c) resources as components of the natural environment [19]. The Russian Constitution stipulates that natural resources fall within the joint jurisdiction of the Federation and the regions (Article 72) and should be utilized and protected as the basis of the life of the people living in the areas from which these resources come (Article 9) [20]. With the transition to a market economy, resources have come to be treated as commodities having economic value and, as such, a target of state regulation. The principal law governing the use of minerals is the Federal Act on Subsoil [21]. According to this act, the Russian Federation is the sole owner of the subsoil, and its ownership right to the subsoil is inalienable. The state grants licenses for the exploration and exploitation of deposits [22]. However, within the state form of 
property of the subsoil, the extracted natural resources, according to the details of the license, may be state, municipal, private or other. Under Russian legislation an owner is entitled to the rights of possession, the use and the disposal of his or her property [23]. Hence, sharing is the transition of natural resources as tangible assets from state hands into the hands of the extractive companies mainly through public arrangements (licenses, agreements, tax relations) and their distribution to the civil society through private-social arrangements.

Land ownership does not entail ownership of the subsoil, and this leads to disputes, especially when extraction industry projects (subsoil users) conflict with the interests of individuals or other entities (usually leasers or other users of land plots) [24]. In the Russian Arctic conflicts concerning land rights often arise between industrial companies and reindeer herders, who continue to practice reindeer herding as a traditional way of life. The right of free prior and informed consent (FPIC) arises from property rights; it is not a free-standing right. FPIC is connected with the traditional lands of indigenous peoples, even if they are not the official owners of the land [25]. In practice, FPIC is not commonly applied, and CSR is more often implemented through benefit-sharing agreements which include all provisions that are important for the business and for the local communities.

This article argues that the implementation and enforcement of benefit-sharing arrangements need to be improved to enable a positive impact on individuals and communities. The article provides an overview of the following concepts: Corporate Citizenship and Stakeholder Management under the umbrella of Benefit-Sharing. The concept of Stakeholder Management is relevant in the Russian North, because there are many stakeholder groups (both indigenous and non-indigenous), and interrelations between industries and stakeholders are continuously changing. The concept of Corporate Citizenship is an appropriate concept in this discourse to discuss corporate behaviour towards stakeholders, particularly communities in the Russian North.

\section{Materials and Methods}

In this article, the aim is not only to study theoretical aspects of benefit-sharing, but also to examine how diverse benefit-sharing concepts may work in the actual context of the Russian Arctic. The analysis of benefit-sharing agreements provides current examples of how voluntary approaches are being implemented and how the interaction between different stakeholders function in Russian localities. The content analysis distinguishes normative approaches of benefit-sharing and links them to the real-life situation in the Russian Arctic. A major objective is to identify benefit-sharing practices and agreements in the Northern areas of Russia and determine to what extent these practices differ from the theoretical normative tools and policies provided by academia and relevant stakeholder organizations.

The analysis of this article focuses on research materials and corporate publications:

- Regional, national and international legislation describing the rights and obligations of local communities and extractive industry projects,

- International business management concepts: Benefit-Sharing, Corporate Citizenship and Stakeholder Management,

- Socio-economic agreements at the regional and municipal levels,

- Sustainability reports and web content of Russian extractive industries companies.

- In addition to legislation, company codes of conduct, and relevant literature were examined.

Socio-economic agreements are one of the core elements of the study (Table 1). In many cases a special request was needed to get access to the agreements, because they are not publicly available. Reaching out to local authorities may allow access to the documents by interested parties. As part of the present research, seven socio-economic agreements on different levels were analysed [26]. Four were found in a publicly available source, and three were obtained by request to the companies. These documents are of high relevance, because they reflect the commitments of the industry and can address the concerns and expectations of local society. 
Secondary literature was utilized to embed this analysis in the findings of previous studies and, in general, in the framework of Russian legislation.

Table 1. Overview of social-economic agreements in the Russian North.

\begin{tabular}{|c|c|c|c|c|}
\hline & $\begin{array}{l}\text { Validity of } \\
\text { Agreement }\end{array}$ & Parties to the Agreement & Main General Provisions & Environmental Provisions \\
\hline 1 & $\begin{array}{l}\text { One year with } \\
\text { possible } \\
\text { prolongation }\end{array}$ & $\begin{array}{l}\text { Oil and Gas } \\
\text { Company/Indigenous } \\
\text { people }\end{array}$ & $\begin{array}{l}\text { Partnership and cooperation, } \\
\text { preserving traditional ways } \\
\text { of life, culture, customs and } \\
\text { language of indigenous } \\
\text { people, educational } \\
\text { opportunities for local youth }\end{array}$ & $\begin{array}{l}\text { Consultations with } \\
\text { indigenous people before } \\
\text { projects start, constant } \\
\text { stakeholder dialogue } \\
\text { Company reports on } \\
\text { violations of environmental } \\
\text { legislation }\end{array}$ \\
\hline 2 & $\begin{array}{l}\text { No validity } \\
\text { information }\end{array}$ & $\begin{array}{l}\text { Mining } \\
\text { company/Municipality }\end{array}$ & $\begin{array}{l}\text { Partnership aiming at the } \\
\text { effective work of company, } \\
\text { participation of municipality } \\
\text { in the management of the } \\
\text { company, social and } \\
\text { investment programs, } \\
\text { labour and educational } \\
\text { opportunities for local } \\
\text { people }\end{array}$ & $\begin{array}{l}\text { Prevention or liquidation of } \\
\text { environmental pollution, } \\
\text { direct compensation to local } \\
\text { people for polluted areas }\end{array}$ \\
\hline 3 & Five years & $\begin{array}{l}\text { Oil and Gas } \\
\text { Company/Indigenous } \\
\text { people }\end{array}$ & $\begin{array}{l}\text { Sustainable economic and } \\
\text { social-cultural development } \\
\text { of indigenous people's right } \\
\text { to use the resources; } \\
\text { recognition of oil and gas } \\
\text { impact on traditional ways } \\
\text { of life, FPIC, need for } \\
\text { consultations }\end{array}$ & $\begin{array}{l}\text { Prevention or mitigation of } \\
\text { any potential adverse } \\
\text { impacts }\end{array}$ \\
\hline 4 & $\begin{array}{l}\text { One year with } \\
\text { possible } \\
\text { prolongation }\end{array}$ & $\begin{array}{l}\text { Oil and Gas } \\
\text { Company/Indigenous } \\
\text { people }\end{array}$ & $\begin{array}{l}\text { Social-economic } \\
\text { development of indigenous } \\
\text { people via social-economic } \\
\text { programs }\end{array}$ & No detailed information \\
\hline 5 & Three years & $\begin{array}{l}\text { Mining Company/Regional } \\
\text { government }\end{array}$ & $\begin{array}{l}\text { Realization of industrial, } \\
\text { financial and social } \\
\text { programs based on the } \\
\text { principles of social } \\
\text { responsibility, transparency } \\
\text { of information }\end{array}$ & Environmental safety \\
\hline 6 & $\begin{array}{l}\text { No validity } \\
\text { information }\end{array}$ & $\begin{array}{l}\text { Mining } \\
\text { Company/Indigenous } \\
\text { People/Municipality }\end{array}$ & $\begin{array}{l}\text { Financial aid within } \\
\text { industrial exploration of } \\
\text { natural resources, } \\
\text { compensation for negative } \\
\text { impacts, preserving the } \\
\text { traditional way of life, } \\
\text { creation of sustainable } \\
\text { development of } \\
\text { municipality, support for } \\
\text { local businesses, purchase of } \\
\text { local production, labour } \\
\text { opportunities for local } \\
\text { people, legal and medical } \\
\text { aid, research and } \\
\text { conferences }\end{array}$ & $\begin{array}{l}\text { Company reports on } \\
\text { violations of environmental } \\
\text { legislation, } \\
\text { Company refrains from any } \\
\text { actions which can cause } \\
\text { economic or environmental } \\
\text { damage, environmental } \\
\text { security }\end{array}$ \\
\hline 7 & Five years & $\begin{array}{l}\text { Oil and Gas } \\
\text { Company/Regional } \\
\text { government }\end{array}$ & $\begin{array}{l}\text { Financial aid aimed at the } \\
\text { infrastructure development } \\
\text { of the region }\end{array}$ & No detailed information \\
\hline
\end{tabular}

\subsection{Corporate Citizenship}

In discussing the benefit-sharing of extractive industries in the Russian Arctic, the concept of Corporate Citizenship is relevant. Being a good corporate citizen implies assuming the social responsibilities for all internal and external processes linked to the business venture. Corporate Citizenship "involves the social responsibility of businesses, and the extent to which they meet legal, ethical and economic responsibilities, as established by shareholders" [27]. This definition 
strengthens the approach that Corporate Citizenship is a sub-field of CSR. Moreover, the term "Corporate Citizenship" can be formulated as a bargain between business and society/state in which business is supposed to have a responsible relation with communities' needs and counts on special preferences [28]. Even though Corporate Citizenship and CSR share many conceptual frameworks, substantial differences are perceivable. CSR embraces a holistic view and covers all types of corporate responsibilities: economic, legal, ethical and philanthropic [29]. Corporate Citizenship is more concentrated on the social (societal) aspects impacted by business operations, and implementation can be done in the form of a management concept such as, for example, implementing a marketing management system or environmental management system. In order to be a good corporate citizen, it is essential to create awareness throughout the entire workforce what this, in fact, means and how this is being applied in everyday working life. Initial policy formulations such as "We want to be a good neighbour to the nearby communities" or "Let's treat the locals with the same respect with which we treat each other within our company" are helpful but not enough. A management mix is required that foresees practical corporate citizenship implementation in a structured and scheduled way. Crucial elements of a corporate citizenship management mix are discussed below and linked to the case of the Russian Arctic industries [30]. In contemporary Russia, the process of the concept's incorporation is explained by historical aspects [31]. The transition from a state-controlled economy to a market-based economy has led to reforms and the adaptation of the companies to the new realities of global trade. The extractive industries in the Russian North apply some tools of Corporate Citizenship, aiming at fulfilling the social objectives in local societies.

Corporate Giving is a tool which provides philanthropic donations, payments or similar financing for local social services. In the Russian Arctic, the allocation of corporate capital for local infrastructure, the health care system, education, housing, pensions and other services is often fundamental to maintain the survival of Arctic communities [32]. The linkage to benefit-sharing is especially evident here, since, in the framework of corporate giving, all corporate capital provided is allocated voluntarily. This does not include capital that has been raised due to mandatory compensation and court decisions or facilitated by political actors. In socio-economic agreements, capital provisions can originate from the Corporate Giving approach, as well as from other elements of the Corporate Citizenship mix.

Similar to Corporate Giving is Corporate Sponsoring, but there is an essential difference. While Corporate Giving follows predominantly the philanthropic cause of capital allocation, sponsoring aims at positive effects for the company providing the capital. The Russian Arctic industries are famous for sponsoring local sports teams associated with sports associations and junior sports affiliated with the school system. Notable sports that receive sponsorship in the Russian North include ice hockey, football, volleyball, basketball and others. Successful sport teams receive local media attention, and firm logos of the sponsors are widely used for marketing purposes. Municipal and regional governments, plugging holes in their budgets, impose an extra tax on companies in the form of social investments. Researchers call those relations administrative enforcement [33] or agreements [34]. In Russia, sponsoring is not implemented sufficiently; companies are continuously spending their income on sponsoring, but the state strives to control and channel it into their own interests.

Cause-Related-Marketing embraces elements of corporate giving and corporate sponsoring. A good example in the Russian Arctic is the continuous cases when oil projects move from exploration to exploitation. The benefits for the regions-employment, infrastructure, donations, sponsoring and other benefits-are communicated to the local and regional communities to improve the image of the company at large and to generate a positive attitude towards the exploitation project in the area among the residents [35].

Corporate volunteering is a form of benefit-sharing developed by philanthropists in the early twentieth century. The idea is to send workers out of the factories to provide social services to the community. In Russia's corporations it is also on the agenda in some regions [36]. Unlike the volunteering approach, with the corporate foundations approach, capital is directly allocated to specific institutions, projects or facilities. The capital-providing company sets up a foundation which 
works, to a large extent, independently of the founding company. Corporate foundations tend to use start-up capital from a company, seeking, in later phases, funding from other sources as well. Some of the large-scale extractive industries have established foundations; however, the corporate-giving approach and sponsoring are much more dominant [35]. Moreover, in regions, there is a lack of socially-orientated non-governmental organizations that can fulfil the functions of corporate sponsored providers, which is why the companies strive to stimulate the creation of such organizations from the ground up, and that takes time and financial resources.

Decision makers in Russian Arctic industries are often closely tied to regional and national authorities, and to improve their reputation, the companies should emphasise local needs, wishes, and expectations among political decision makers in the regions and in Moscow. Social lobbying is a form of corporate citizenship that has the potential to improve relations between companies, residents and authorities [35]. It could be used in a sort of deal-making wherein the local communities support projects and do not hinder them with protests, complaints or campaigns, and the company "lobbyists" promote initiatives that are important for the regional community, such as the revision of specific laws, tax deductions or larger shares of public capital allocations.

Venture philanthropy is similar to social lobbying, but instead of attending to local needs within a political framework, the idea is that corporate actors use their connections in the global investment sector to support the local communities' access to social capital investments. In the Russian Arctic, this concept is theoretical in nature because practical application of it rarely happens. However, Russian corporations with ties to sparsely populated areas in the far North may consider this option in the future, as these local populations certainly have obstacles to getting access to international social-risk capital. Bilateral agreement between local communities and industry is at the heart of the public-private partnership concept as well. These partnerships embrace the idea that corporations and non-profit public organizations bundle their resources and try to achieve a common goal. Either the public organization or the company can initiate the contact with the other party, and usually the partnership leads to a specific project to improve societal well-being. Even though the Russian Arctic has seen a few of these partnerships, there is certainly room for improvement in terms of resources allocated and the desire to achieve common goals.

\subsection{Stakeholder Management/Stakeholder Value:}

Another concept from the field of management studies with relevance to benefit-sharing is the stakeholder management approach as coined by Ed Freeman in 1984 [37]. His work can be considered as a paradigm shift in business management as it substantially questions the idea of emphasising shareholder values, predominantly widening the perspective to include stakeholders' needs and expectations. Shareholders' values have a narrow focus on investors and business partners but neglect crucial actors such as customers, consumers, nearby communities, environmental activists, trade unions and many others. Stakeholder management has a connection to CSR as well [29,38]. Proponents of the shareholder value concept, such as Morgan Friedman (Chicago School of Economics), argue that the most important, if not only, social responsibility is profit generation in order to cover the costs in terms of bills, staff and shareholder dividends, and consequently make it possible to survive in the market [39]. Freeman was the one who eventually challenged this way of thinking and developed the idea that companies that take stakeholder needs into account have much better chances to be successful in the long-term perspective, for various reasons [29,37].

Stakeholder management involves various components that must be organized in a chronological manner. The first step is that the corporation needs to identify the stakeholders. The challenge here is to include all stakeholder groups and not being satisfied too quickly with a list of only a few [38]. In the age of blogs, vlogs, social media and other internet channels, it is easier than ever before for non-recognized stakeholders to raise their voice and explain their opinions to a wider audience [40]. Once all stakeholders have been identified, the analysis of stakeholder expectations and possible ways of cooperation are on the corporate agenda. This analysis implies a comprehensive definition of all 
benefits the business venture may allow and how stakeholders could or should benefit from this. Benefits can be categorized into infrastructure development, community well-being and benefits that the company should provide when it is fair and just to do so. Examples of the latter are compensations if living conditions are compromised or if a company disturbs the livelihoods of people who were in the area before the industry arrived. Stakeholder management is not only the appeal to awaken ethical behaviour in corporate decision makers or promote corporate philanthropy [38]. Ignoring stakeholders' voices carries many risks for a corporation. Conflicts with environmental activists and local communities tend to be very costly and sometimes even lead to corporate insolvency [40]. Demonstrations at factories and strikes by the workforces that bring production facilities to a standstill are connected, in most cases, with enormous losses. Moreover, conflicts can ruin the corporate image, which needs to be solid to attract customers, investors, supply chain partners and the most talented employees [40]. From this follows the crucial element of stakeholder dialogue, which is a continual element in the chronology of stakeholder management [38]. Through proactive communication channels, corporate decision makers can learn what matters for the stakeholder communities; this is the prerequisite for a path towards consensus building and conflict prevention [38].

The concept of stakeholder management plays a crucial role as diverse actors are linked to the Russian Arctic and the extractive industries at large. Russia is a land of diverse ethnicity. Many different cultures, indigenous and non-indigenous, call the Arctic home, and they are stakeholders in numerous projects in oil and gas exploitation, mining and forestry.

Thanks to stakeholder management, shortcomings in Russian Arctic industries have become evident at present. The identification of stakeholder groups is often insufficient, limited in many cases to the residents of an exploitation area [32]. International actors, such as representatives of nongovernmental organizations that are concerned about ecological or societal matters, are usually not identified, or, if identified, are not included in the stakeholder dialogue [32]. For those actors who are in dialogue with the industry, it has generally been the case that public hearings or meetings have been misleading. Sometimes the corporations conduct a monologue and perceive their duties as being fulfilled by informing the public about the corporate plans. In other cases, stakeholders use the opportunity to speak to the community to raise issues that are not linked to the corporate activities, but in many cases to the municipality [41]. Discussing topics that are not related to the project cannot lead to consensus building regarding the potential conflicts between the parties. Thus, stakeholder management must be conducted in such a way that all parties understand the others' positions. Social media channels allow stakeholders to present their concerns to a wider public. Even though such opportunities are also rising in the high latitudes of Russia, the opportunity to use the internet as a tool to gain attention for local expectations and demands towards the industry is not used very much by Russian Arctic stakeholders. The diversity of the ethnic groups facing the ongoing influx of extractive industries in the Russian Arctic and the different interests of these groups make it difficult to define a common stakeholder position [32]. While some stakeholders work for the companies themselves or belong to the supply chain, others are occupied in traditional livelihoods (for example, fishery or reindeer herding) or practice businesses that could be undermined by extractive industries, such as agriculture or tourism. Failure to reconcile the different opinions of the stakeholders can weaken the stakeholders' position towards a corporation and lead to minimum compliance with the demands of the most critical stakeholders [16,32]. Benefits perceived by stakeholders which have positive attitudes are often utilized for marketing purposes by companies in their sustainability reports, advertisements and other corporate publications. Whereas stakeholder protests in many countries have led to improvements in the situation of the stakeholders, to this date demonstrations in Russia have rarely led to significant changes. Socio-economic agreements are, in many cases, the outcome of informational meetings, but not meetings characterised by a fruitful debate [41]. Stakeholders in Russia must find ways to build stronger consensus among themselves and should appoint spokespersons who are continually in dialogue with the corporate decision makers, as well as with the authorities and 
media [32,41]. Proactivity is not only a prerequisite for successful businesses, but also needed from stakeholders for a successful realization of their demands [38].

\subsection{A Regulatory Framework for Extractive Industry Contracts}

The legal bridge between the extractive industries and its stakeholders in the Russian Arctic is upheld through the establishment of bilateral or multilateral contracts [32]. The negotiation of these contracts is one element of Stakeholder Management. Russian contract law is based on market economy principles with respect to civil rights and the liberties of individuals and legal entities, equality of parties, freedom to make contracts, and inviolability of property. According to the Civil Code of the Russian Federation, a contract is an agreement of two or several entities aimed at establishing, changing, or terminating civil rights and duties [23]. Any company has a right to formulate and enter into any contract which is not prohibited by law. This legal definition reflects the traditional approach of Roman-law-based systems, which consider a contract as an agreement [22].

In the oil and gas sector there are different special aspects involved in the preparation and management of international oil/gas contracts, foreign investment agreements, and model contracts. Some of those contracts have analogues in the Russian contract system, but some contracts require adaptation before they can be used in the conditions of Russian legal realities. Some forms of contracts are subject to the provisions of the legislation, e.g., the Federal Law "About production sharing agreements" [42]; some contracts, however, are the "fruits" of business practices and regulated only by corporate norms and the general principles of the civil code. The author will provide an overview of the contracts which are often used to implement CSR policies of oil/gas and mining companies and will analyse voluntarily made socio-economic agreements because all the other above-mentioned contracts are rarely publicly available since they contain confidential information on investment projects.

\subsection{Contracts with Regional and Local Governments}

In addition to such commonly used primary investment contracts as production-sharing agreements and joint-venture agreements, each type of contract differs from the others. For example, socio-economic agreements may be called Community Development Agreements or Host Government Agreements (HGAs) [43].

For the most part, previous research focusing on the terminology of benefit-sharing has not focused specifically on the concept but covered the theme by embedding it in other discourses, such as Corporate Social Responsibility or environmental and social challenges caused by the operations of Russian industries. A few relevant studies that put benefit-sharing at the centre of the analysis are outlined in this paragraph. The issue of benefit-sharing agreements has been raised by Tysiachniouk, Petrov and Tulaeva [6,44], Britcyna et al. [41], Wilson [45], Chaknazarov [17] and Novikova [46]. Tysiachniouk, Petrov and Tulaeva define different benefit-sharing modes, observing cases in the Russian Arctic and Alaska. Wilson utilizes the concept of benefit-sharing in the framework of social licence to operate. Britcyna et al. see benefit-sharing agreements as a practical tool that can be utilized by local communities to achieve participatory rights. Novikova criticises in her work the fact that indigenous communities in the Russian North do not strive to broaden the agreements in terms of novel solutions that improve local well-being and the preservation of the ecosystem. According to Novikova, in many cases indigenous groups take monetary compensation based on a pre-determined benefit-sharing agreement, but do not seek other benefits that may be more valuable for the community in the long run; she is critical of the practices of making social-economic agreements in Russia. Chaknazarov indicates in his research that local groups have different opinions concerning benefit-sharing agreements. While some local groups in Russia welcome monetary compensation as an income source that has prevailed, other groups are very critical and perceive the agreements only as a formality that has no real impact. The present article is an initial step towards focusing on negotiation processes between industrial companies and interested parties to pursue legal actions; 
it will consider a broader scope of social, environmental and human rights in the context of the Russian extractive industry.

Socio-economic agreements are contractual agreements made by a company with regional governments/municipalities or non-governmental organizations with the aim of providing benefits to the localities in exchange for the acceptance of industrial projects. The Russian regions have different socio-economic backgrounds, and companies usually do not have a single template for contracts; they reflect the needs of the parties depending on the social context, or the template may be provided by the region/municipality [47]. Sometimes, the elaboration of the agreements may take several years before it is completed $[47,48]$. When concluding these agreements, the parties usually do not provide a great deal of detailed information in the agreement, which contains a preamble specifying the names of the parties, the date and place, and the goal of the agreement: e.g., "on the one hand, the company will develop the fuel and energy industry in the region, improve the region's economic situation, and maintain the social stability and social welfare of the region, and, on the other hand, the government is obliged to take steps to ensure a positive investment environment for all business entities" and some other general provisions [41].

The main objective of such agreements is to bring permanent improvements to the lives of local communities which tend to be more strongly affected by negative impacts of industrial operations. Usually, there are no detailed provisions concerning, e.g., the environment (losses or damages) or detailed provisions concerning what the region is entitled to do in favour of the oil/gas companies. Those socio-economic agreements at the regional level consist of a list of infrastructure and facilities the companies will support; those objects of support are usually the most crucial ones that the regional budget cannot cover [41]. Usually the period of the contract is negotiated; the agreement is generally made for five years with a prolongation period. The agreements are confidential, so they are not transparent. Some sums and a few excerpts from the contracts may be published online, but the whole contract is not publicly available.

A company or a subsidiary can conclude these agreements with municipalities, too. Those agreements are commonly concluded with the territories where the extraction takes place. The benefits provided by the companies are aimed at the health sphere, education, culture and sport. Payments to local municipalities are essential; the budgets of the regions and municipalities are often insufficient to serve local societal needs. The parties to the agreement confirm that they will abide by and satisfy the terms of the agreement. However, as for contracts at the regional or municipal levels, the local people cannot track and scrutinize payments or estimate expenditures, which may leave room for distrust or even corruption. The local communities can express their opinions about which projects would be important for them, but it is unclear to what extent these opinions will be considered by the local mayor who concludes the agreement [44]. Proper negotiation and drafting of the financial provisions in such contracts are essential. These contracts have not typically served as a primary source of contractual responsibility on which individuals and local communities can rely; they are not transparent, and the nature of the contracts is not clear enough for all the stakeholders.

Residents would better understand the complex nature of extractive agreements and the responsibilities of the interested parties, including government, company and society, if the agreements were well-developed and framework agreements were available online. In some cases, when an agreement is made, it is possible that "significant inequities in knowledge and power between indigenous peoples and companies" will result in definitions of fair and equitable benefit-sharing "that are predominantly shaped by the latter" [49]. Yet some of the agreements have started to reflect detailed descriptions of company allocations and have an online presence [48]. This could be an example for other companies to follow good corporate practices. The concerns and expectations of the residents must be heard and respected and, consequently, consensus must be built. This is a prerequisite for being a good corporate citizen, as discussed earlier in this article [31]. The agreements do not ensure full compensation, because industrial operations cause complex damage to the social, economic, environmental and cultural development of the territories [50]. 


\subsection{Company-Local Community Contract}

The companies also make contracts with so-called "patronaged" parties. "Patronaged" parties may include commercial and non-commercial organizations of the local communities. Very rarely is there an agreement or financial aid to the individuals directly [41]. Concluding agreements with local communities has a long tradition in extractive industry projects abroad [6,51]. In concluding agreements at the local level, the companies pursue different objectives. For example, to operate on lands which are leased by reindeer herders (to include part of a land plot in a sublease), the agreement must be concluded to get the consent of the herders. In practice, the form of the contract does not need to be in written form, nor necessarily expressed in monetary terms [6]. Benefits can be provided for communities. For example, in-kind benefits aim at giving compensation for affected resources or lessening the risks created by a facility. Not just social issues are in the focus of agreements with local communities; the agreements can include environmental provisions or provisions concerning participatory rights or the monitoring of the oil spills situation [41] or reporting on whether the environmental laws are being respected. Compensations to local people for environmental damage caused by companies is one of the pressing issues at the negotiating table. The parties try to solve this issue, using the tools of corporate citizenship, rather than by making claims to the authorities [52].

Contracts at the local level are usually concluded for a short term-a year-and do not guarantee the stability of the relationship between the parties. The "patronaged" parties sometimes do not have the freedom to choose which provisions should be included in the documents; they follow the formal practices and do not amend the contracts [46]. They are not a totally equal party in the contracting process, and do not enjoy the principle of freedom of contract fully. Not all socio-economic agreements are specifically formulated. General statements, such as the sustainable development of the indigenous people or local support, are included but the documents lack provisions for concrete actions. How the actual benefit looks is a matter of interpretation. The capital allocations do not lead to prosperity growth of the local communities and do not cover all their damages and losses $[17,51]$. The communities should know where and how the natural resources and benefits are being distributed.

The broad range of stakeholders should be included in the negotiation process at all levels: socio-economic agreements, community, local and regional-level agreements. Transparency is also needed for all contracts [53,54]. Nevertheless, though the socio-economic agreements include some environmental statements, the real nature of the agreements is economic [46]. To utilize these agreements properly, local groups and municipalities must negotiate with the companies thoroughly and must agree among themselves what matters in the region. Companies can utilize the agreements by fulfilling common goals (e.g., infrastructural development, support of local suppliers and social entrepreneurship) that benefit all actors involved. Being specific and detailed in the agreements reduces the risk of conflicts and allows companies to engage in successful reputation building. Social partnerships agreements are not always publicly available in Russia. If the actors decide to give free access to actors outside the signatories, it will create credibility and transparency. These are assets that multinational companies can develop very well in their CSR strategies and CSR communication [32].

\section{Discussion and Conclusions}

Benefit-sharing in the Russian Arctic can be achieved by diverse concepts and practical approaches. The extractive industries can follow voluntary initiatives based on Corporate Citizenship. Since land-use conflicts, environmental deterioration and a lack of state-funded social services are evident in large parts of the Russian Arctic, it is essential to establish legally binding agreements for all parties involved. When resources are extracted in a territory, the natural environment and local sources of livelihoods are often compromised and deteriorated. Compensation and internalization with respect to negative impacts need to be arranged to maintain local livelihoods and company-community relations. In theory, legally binding agreements in the form of company-local community contracts may be superfluous if the performance of the company is perfectly in line with common practices of corporate citizenship. This is, of course, rather a normative idea and does not reflect the situation in real life. 
Stakeholders in the Russian Arctic and NGOs criticize the extractive industries for diverse reasons, often linked to environmental pollution. Contracts are needed to share the benefits provided by the value chain of extractive industries in the Russian North. The Russian Arctic demonstrates clearly that both legally binding and voluntary approaches are needed to achieve stable relations between all actors involved. This is, moreover, a prerequisite to gaining socio-economic stability in the region and keeping ecological footprints to a minimum. Effective implementation of environmental laws should have priority in setting rules and protecting the local peoples' rights and way of life. To enable the provision of benefits, private arrangements should not merely replace or duplicate the norms of law.

Based on the findings this article suggests some practical implications. Modern businesses within and outside Russia need management processes beyond the basic business process such as production and services. Nowadays, practical implementation of the practices mentioned above in all operations and processes is crucial to achieve the desired results, such as stakeholder benefits and a strong societal position of the company in the community. Thus, managerial steps include setting up communication platforms via diverse channels. Traditional stakeholder meetings are as relevant as the utilization of digital solutions (e.g., sustainability reports and website announcements). In practice, every company in the Russian Arctic should assess the local stakeholders and determine their demands and expectations. Assistance from consultants from private firms and academia are often helpful to avoid incomplete assessments. The stakeholder universe seems simple within the Arctic context, but it is, in fact, very complex and ends at local borders. A globalized society links extractive industries in the Arctic to both local and remote stakeholder groups. In this regard, an understanding of the distinction between stakeholder management and corporate citizenship is important. Both concepts were introduced to cover holistically the benefit-sharing narrative. As explained above, stakeholder management embraces all groups, whereas corporate citizenship connects companies more closely to the local context (being a good neighbour). To find the right balance and complete coverage requires dialogue internally among decision makers and the work-executing staff, as well as with external experts and the stakeholders themselves.

Benefit-sharing is an ongoing discourse in the Arctic, and important trends such as strong climate change impacts in the Arctic and urbanisation make it necessary for management boards to be continually up-to-date with the developments. The composition of local communities changes due to fly-in/fly-out workers, the growing Arctic tourism sector, and natural in- and out-migration flows. Companies must react in a timely fashion to local societal changes, and the management tools discussed in this article are a valid starting point to keep on track in planning and execution processes.

The case of the Russian Arctic shows that specific benefit-sharing arrangements need to be improved. Stakeholder dialogue is often only informational, and corporate citizenship practices focus mainly on charity and philanthropic approaches. The benefits generated are crucial for the local economies, and resource extraction in the Russian Arctic is obviously the backbone of the Russian economy. Hence, socio-economic agreements in the form of company-community contracts are desired by stakeholders. The industry receives criticism from community representatives and stakeholder organizations addressing non-transparent bilateral contracts. Access to these documents is difficult even for residents of the communities affected by the agreements.

Moreover, the monetary compensations given are often controversial. The stakeholders perceive that monetary compensations do not cover the negative impacts caused by extractive operations. In some cases, compensations go to municipal bodies and serve only the regional budget to cover debts or cover administrative costs and are not transferred top-down to the residents whose lives and livelihoods are affected by the extractive industries. Russian municipalities receive payments from the extractive industries; partly, therefore, they lack the motivation to generate wealth for the region themselves by developing regional business strategies and effective austerity plans. One result of the analysis of the present research is that local communities and authorities need to be more active in negotiations with the industry as well as with political decision makers. Residents need to be active to receive their share of the benefits by raising their voices in stakeholder dialogues, negotiations, 
and social media. Consensus can be built only through communication and if all parties understand the other parties' positions and their opinion on specific issues. To conclude, communication is the key to benefit-sharing agreements in the Russian Arctic in order to build mutual trust, local as well as national well-being among stakeholders, and establish well-functioning future relations.

Funding: This research was supported by the Academy of Finland's Arctic Academy Programme "Oil Production Networks in the Russian Arctic," no. 286791.

Conflicts of Interest: The authors declare no conflict of interest.

\section{References}

1. Schroeder, D. Benefit-sharing: It's Time for a Definition. J. Med. Ethics 2007, 33, 205-209. [CrossRef] [PubMed]

2. Blanco, E.; Razzaque, J. Globalization and Natural Resources Law; Edward Elgar Publishing: Cheltenham, UK, 2011; pp. 212-245.

3. World Business Council of Sustainable Development. WBCSD—Corporate Social Responsibility. September 1998. Available online: http://www.wbcsd.org/DocRoot/hbdf19Txhmk3kDxBQDWW/CSRmeeting.pdf (accessed on 28 February 2019).

4. Eliseev, Y.; Naumova, V. Economic Development of the Russian Arctic: Objectives and Approaches. Trydi KarNC RAN. 2015. Available online: https://cyberleninka.ru/article/n/ekonomicheskoe-osvoenie-rossiyskoyarktiki-tseli-zadachi-podhody (accessed on 12 March 2019).

5. Morgera, E. The Need for an International Legal Concept of Fair and Equitable Benefit-sharing. Eur. J. Int. Law 2016, 27, 353-383. [CrossRef]

6. Tysiachniouk, M.; Petrov, A. Benefit-sharing in the Arctic Energy Sector: Perspectives on Corporate Policies and Practices in Northern Russia and Alaska. Energy Res. Soc. Sci. 2018, 39, 29-34. [CrossRef]

7. Business Dictionary. Available online: http://www.businessdictionary.com/definition/benefit.html (accessed on 28 February 2019).

8. Yin, J.; Zhang, Y. Institutional dynamics and corporate social responsibility (CSR) in an emerging country context: Evidence from China. J. Bus. Ethics 2012, 111, 301-316. [CrossRef]

9. Hong, H.; Kubik, J.D.; Scheinkman, J.A. Financial Constraints on Corporate Goodness; National Bureau of Economic Research: New York, NY, USA, 2012; p. 3.

10. Fidler, C.; Hitch, M. Impact and Benefit Agreements: A Contentious Issue for Environment and Aboriginal Justice. Environ. J. 2007, 35, 49-69.

11. Kobzii, A.; Novak, M.; Kozlova, E. Influence of Russian Oil Industry on the Country's Economy and Prospects of Solving This Dependence. Innov. Econ. 2018, 7, 211-216.

12. North, D.C. Institutions, Institutional Change and Economic Performance; Cambridge University Press: Cambridge, UK, 1990.

13. Lanshina, T.A.; Laitner, J.; Potashnikov, V.Y.; Barinova, V.A. The Slow Expansion of Renewable Energy in Russia: Competitiveness and Regulation Issues. Energy Policy 2018, 120, 600-609. [CrossRef]

14. Larchenko, L.V. Contemporary Arctic: The Problems of Exploration and Social-Economic Development. Reg. Econ. 2011, 11, $2-7$.

15. Kornai, J. The Socialist System: The Political Economy of Communism; Princeton University Press: Princeton, NJ, USA, 1992; p. 226.

16. Crotty, J. Corporate Social Responsibility in the Russian Federation: A Contextualized Approach. Bus. Soc. 2016, 55, 825-853. [CrossRef]

17. Chaknazarov, S.H.; Relations between Indigenous People of the North and Industrial Companies. Relations between Indigenous People of the North and Industrial Companies. Case Ygra. AIS 2018, 30. Available online: https://cyberleninka.ru/article/n/k-voprosu-o-vzaimodeystvii-korennyh-narodovsevera-i-promyshlennyh-kompaniy-na-primere-yugry (accessed on 17 March 2019).

18. Jernelöv, A. The Threats from Oil Spills: Now, Then, and in the Future. Ambio 2010, 39, 353-366. [CrossRef]

19. Petrov, V.V. Environmental Law; Moscow.; B.E.K.: Moscow, Russia, 1995; pp. 423-424.

20. Moscow, M. (Ed.) The Constitution of the Russian Federation. Rossiiskaya Gazeta. 25 December 1993. Available online: http://www.constitution.ru/en/10003000-01.htm (accessed on 12 January 2019). 
21. Federal Law on Subsoil No. 2395-1. 1992. Available online: http://cis-legislation.com/document.fwx?rgn= 1494 (accessed on 12 January 2019).

22. Klimova, $\mathrm{O}$. The question concerning the right of ownership of the subsoil. Nedvizhimost' $i$ investicii 2010, 3, 44. Available online: http://dpr.ru/journal/journal_42_20.htm (accessed on 14 February 2019).

23. Civil Code of the Russian Federation. Part One. 1994. Available online: https://www.wipo.int/edocs/lexdocs/ laws/en/ru/ru083en.pdf (accessed on 14 February 2019).

24. Ignatyeva, M.N.; Loginov, V.G.; Balaschenko, V.V.; Kubarev, M.S. Propriety Rights on Natural Resources. UGGU 2018, 3, 142-149.

25. Hanna, P.; Vanclay, F. Human rights, Indigenous peoples and the concept of Free, Prior and Informed Consent. Impact Assess. Project Apprais. 2013, 31, 146-157. [CrossRef]

26. Interaction of Indigenous Peoples and Industrial Companies (Practices, Forms of Partnerships, Documents). Federal Council Publisher, 2009. Available online: http://council.gov.ru/media/files/41d44f243f298c2efb01.pdf (accessed on 11 January 2019).

27. Investopedia. Available online: https://www.investopedia.com/terms/c/corporatecitizenship.asp (accessed on 10 January 2019).

28. Simpsons, S.; Turkin, S. Social Dimension in Business; Moscow, M., Ed.; Red Square: Moscow, Russia, 2001; p. 25.

29. Carroll, A.B. The Pyramid of Corporate Social Responsibility: Toward the Moral Management of Organizational Stakeholders. Bus. Horiz. 1991, 34, 39-48. [CrossRef]

30. Dubielzig, F.; Schaltegger, S. Corporate Citizenship; Handlexikon Public Affairs: Münster, Germany, 2005; pp. 155-164.

31. Votchenko, E.S. Development of CSR in Russia: From State Paternalism towards Corporate Citizenship; Kaspiiskii region: Politika, Ekonomika, Kul'tura, Russia, 2016; pp. 71-77.

32. Crotty, J.; Rodgers, P. Sustainable Development in the Russia Federation: The Limits of Greening within Industrial Firms. Corp. Soc. Responsib. Environ. Manag. 2012, 19, 178-190. [CrossRef]

33. Chirikova, A.E. State and Business: Relations in the Field of Social Politics in the Contemporary Russia; New Chronograph: Moscow, Russia, 2012.

34. Shishkin, S.V. Business in the Social Politics: Debtor, Donator or Partner? GU-VSE; Independent Institute of Social Politics: Moscow, Russia, 2005.

35. Tulchinskiy, G.L. Corporate Social Investments and Social Partnership: Implementation Techniques and Performance Estimation, 2nd ed.; NRU Higher School of Economics: Saint Petersburg, Russia, 2012; pp. 37-49.

36. Bataeva, B.S. Corporate Citizenship. Russian Realities. Finance and Credit 2004, 9147, 78.

37. Freeman, R.E. Strategic Management: A Stakeholder Approach; Pitman: Boston, MA, USA, 1984.

38. Clarkson, M.B.E. A Stakeholder Framework for Analysing and Evaluating Corporate Social Performance. Acad. Manag. Rev. 1995, 20, 92-117. [CrossRef]

39. Friedman, M. The Social Responsibility of Business Is to Increase its Profits. New York Times Magazine, 13 September 1970; 32-33, 122-124.

40. Husted, B.W.; Milton de Sousa-Filho, J. The impact of sustainability governance, country stakeholder orientation, and country risk on environmental, social, and governance performance. J. Clean. Prod. 2017, 155, 93-102. [CrossRef]

41. Britcyna, E.; Nystén-Haarala, S.; Pappila, M. Extractive Industries and Public Participation in Russia: The Case of the Oil Industry in Izhemskii District, Komi Republic. In The Yearbook of Polar Law Online; Brill|Nijhoff: Leiden, The Netherlands, 2018; pp. 131-163.

42. Federal Law № 225-FZ on Production Sharing Agreements. 1995. Available online: https://www.wto.org/ english/thewto_e/acc_e/rus_e/WTACCRUS48A5_LEG_99.pdf (accessed on 14 February 2019).

43. Foster, K. Community Participation in Development. Vanderbilt J. Transnatl. Law 2018, 39. Available online: https://ssrn.com/abstract=2991233orhttp://dx.doi.org/10.2139/ssrn.299133 (accessed on 10 January 2019). [CrossRef]

44. Tulaeva, S.; Tysiachniouk, M. Benefit-Sharing Arrangements between Oil Companies and Indigenous People in Russian Northern Regions. Sustainability 2017, 9, 1326. [CrossRef]

45. Wilson, E. What is the Social License to Operate? Local Perceptions of Oil and Gas Projects in Russia's Komi Republic and Sakhalin Island. Extr. Ind. Soc. 2016, 3, 73-81.

46. Novikova, N.I. Indigenous People of the Russian North and Oil Companies. Arctic Econ. Ecol. 2013, 3, 106. 
47. A New Agreement with Indigenous People Will Appear in Yakutia. 2018. Available online: http:// yakutiakmns.org/archives/836 (accessed on 12 January 2019).

48. Sakhalin Tripartite Agreement. 2010. Available online: http://www.sakhalinenergy.ru/media/user/libraryeng/ socialstake/minorities/SIMDP_2_eng.pdf (accessed on 10 January 2019).

49. Vermeylen, S. Contextualizing 'Fair' and 'Equitable': The San's reflections on the Hoodia benefit-sharing agreement. Local Environ. 2007, 12, 423-436. [CrossRef]

50. Haller, T.; Bloenchlinger, A.; Marthaler, E.; John, M.; Ziegler, S. Fossil Fuels, Oil Companies, and Indigenous Peoples: Strategies of Multinational Oil Companies, States, and Ethnic Minorities. Impact on Environment, Livelihood and Cultural Change; LIT Verlag Münster: Hamburg, Germany, 2007; p. 610.

51. Loginov, V.G.; Ignatyeva, M.N.; Balashenko, V.V. Ethnic Social and Ecosystem Approach to the Evaluation of the Lifehoods of Small Indigenous Peoples of the North. Econ. Region 2018, 14, 896-913. [CrossRef]

52. Kosorukov, A.A. Corporate Citizenship as a Partnership between State and Business in Public Sector. Available online: http://e-notabene.ru/pr/article_21739.html (accessed on 3 April 2019).

53. Rosenblum, P.; Maples, S. Contracts Confidential: Ending Secret Deals in the Extractive Industry; Revenue Watch Institute: New York, NY, USA, 2009.

54. Tysiachniouk, M.; Henry, L.A.; Lamers, M.; Tatenhove, J.P.M. Oil and Indigenous People in Sub-Arctic Russia: Rethinking Equity and Governance in Benefit-sharing Agreements. ERSS 2018, 37, 140-152. [CrossRef]

(C) 2019 by the author. Licensee MDPI, Basel, Switzerland. This article is an open access article distributed under the terms and conditions of the Creative Commons Attribution (CC BY) license (http://creativecommons.org/licenses/by/4.0/). 